\title{
REGSVORMING EN REGSHANDHAWING IN DIE TOEKOMS, GEBASEER OP DIE GRONDSLAE VAN DIE VERLEDE: 'N TAAKSTELLING
}

\section{Inleiding}

Regsvorming is kultuurvorming en as sodanig val hierdie tipe van kultuurvorming binne die algemene tema van hierdie lesings, naamlik kultuurbestemming. Rondom die stelling dat regsvorming kultuurvorming is ontstaan 'n menigte vrae wat van diep-ingrypende betekenis is en wat 'n wysgerige, meer bepaaldelik 'n regswysgerige, onderbou veronderstel waarop ingegaan moet word om die onderwerp in wat m.i. die juiste perspektief is te sien. Voordat hierop ingegaan word wil ek dadelik sê dat ek regshandhawing binne die bestek van die tema as 'n onderdeel van die proses van regsvorming sien en dit as sodanig wil behandel. Vanselfsprekend moet die behandeling, soos die tema vereis, aansluiting by die verlede vind maar dan tog so dat daar een en ander aan die lig kom wat hopelik as riglyne vir die toekoms mag dien.

\section{Wysgerige grondlegging}

Regswetenskap is 'n vakwetenskap en, soos dit nie hier hoef betoog te word nie, het elke vakwetenskap sy filosofiese grondslae en, as ons inderdaad eenheid in die wetenskap wil verkry, moet die filosofiese grondslae van die verskillende vakwetenskappe hul oorsprong in 'n wysgerige beskouing vind wat at totaalwetenskap ' $n$ visie op die werklikheid en die mens, as deel daarvan, gee wat so 'n cenheidsgrondslag daarstel en ook antwoord gee op die diepste lewensvrae wat die menslike denke beroer. Daar is inderdaad niks waarna die mens, in sy naiewe en teoretiese denke, so na smag as sekerheid oor die antwoorde op die diepste lewensvrae waarvoor hy te staan kom nie. Om hierdie sekerheid in die menslike rede te soek, soos Descartes met sy befaamde cogito ergo sum probeer doen het, is om in die dogma van die soewereiniteit van die teoretiese denke te verval, 'n dogma wat vandag, ten spyte daarvan dat dit nog steeds aanhangers het, tog as 'n uitgediende leerstelling beskou moet word. Die verloop van die geskiedenis van die Westerse wysgerige denke bewys dit dan ook. Ná Descartes het die rasionalisme vir 'n lang tyd die teoretiese denke van 
die Weste beheers, maar ná Kant het dit 'n irrasionalistiese wending geneem en die gangbare wysgerige beskouings, veral die eksistensialisme, is vandag nog in wese irrasionalisties.

As die verlangde sekerheid nie in die menslike rede gevind kan word nie dan kan dit alleen in die geloof gesoek word, want niks is so seer 'n kenmerk van die geloof as juis sekerheid nie. As die wysbegeerte as totaalwetenskap dus in die geloof gefundeer moet word, soos dit trouens deur die eeue heen inderdaad die geval was met die wysgerige denke, dan vereis dit 'n transendentale grondlegging, d.w.s. 'n grondlegging wat die wysgerige denke eers moontlik maak. So 'n grondlegging bestaan uit 'n aantal stellings wat in die geloof aanvaar word en wat dan as uitgangspunt van die wysgerige denke dien. Omdat hierdie stellings in die geloof veranker sit dien hulle ook as denkmotief, d.w.s. as die dryfkrag agter die wysgerige denke. Dit is wesenlik gemeenskapsmotiewe. Herman Dooyeweerd het vier sulke denkmotiewe opgespoor wat, volgens hom, die Westerse wysgerige denke deur die eeue heen beheers het, naamlik die denkmotief van vorm en materie wat die antieke denke beheers het; die skolastiese denkmotief van natuur en genade van die Middeleeue en die humanistiese denkmotief van natuur en vryheid wat vandag nog die dryfkrag agter die heersende wysgerige denkrigtings in die Weste is. Hierdie denkmotiewe is wesenlik onskriftuurlik en die dialekties van aard. Die vierde denkmotief, wat as transendentale grondlegging van die wysbegeerte kan dien, is die wat gebaseer is op die sentrale boodskap van die Bybel, naamlik skepping, sondeval en verlossing deur Jesus Christus in die gemeenskap van die Heilige Gees. Dit is m.i. die werklike transendentale grondlegging van die Wysbegeerte van die Wetsidee wat onder leiding van Dooyeweerd en Vollenhoven opgekom het.

Die groot voordeel van hierdie grondlegging van die wysbegeerte is dat die wortel daarvan dieselfde is as die wortel van ons Christelik-nasionle lewens- en wêreldbeskouing en dat ons naiewe en teoretiese denke, wat uiteraard in verskillende rigtings uiteengaan, tog nie, wat die denkmotief en uiteindelike resultate betref, in stryd met mekaar kan kom nie.

\section{Die skeppingsorde}

As ons twee het, Skepper en skepping, kan ons na die 
verhouding tussen die twee vra. Om die skeiding tussen die twee skerp en suiwer te hou, word die wet as grens tussen Skepper en skepping aanvaar. Wat bo die grens staan is God as die Skepper en Oorsprong van alle dinge. Hier pas die woord van Calvyn: Deus legibus solutus est, sed non exlex. Wat onder die wet as grenslyn staan, en dit is die hele kosmos met die mens as die kroon daarvan, omdat die mens na die beeld van God geskape is, is aan die wet onderworpe. Daar is dus 'n skeppingsorde waaraan die mens sy denke kan oriënteer. Dink maar aan die lex aeterna, wat so dikwels in die wysgerige denke opduik, en aan die sogenaamde natuurreg wat vandag nog 'n bron van verwarring in die regswetenskap is. Die mens snak na vastigheid buite homself en dit soek hy in wat as die Oorsprong van alles beskou kan word. Die Christen-wetenskaplike glo dat die God van die Bybel Skepper en Oorsprong van alle dinge is, maar dan pas dit so 'n wetenskaplike om nie, soos Spinoza, spekulatief oor God te dink nie maar om sy denke binne die perke van die Godsopenbaring te hou.

Die verhouding tussen Skepper en skepping is, wat die mens betref, 'n transkosmiese en derhalwe 'n religieuse verhouding. Die transendentale grondlegging van die wysbegeerte is derhalwe ten diepste religieus gefundeer. Dit is hierdie feit wat aan die denkmotief, dus aan alle wysbegeerte, ten grondslag lê en dit sy dryfkrag gee, want die religie lê beslag op die hele mens in sy hart waaruit die uitgange van die lewe is. Die lewensfunksies van die mens, met insluiting van sy denke, naief sowel as teoreties, is derhalwe religieus bepaal.

Terloops mag hier vermeld word dat deur die sondeval en verlossing as deel van die transendentale grondlegging van die wysbegeerte te aanvaar, 'n pad deur die ontsettende probleem van abnormaliteit gebaan word en alle wysgerige verlossingslere tersyde gestel kan word

Dit is egter die aanvaarding van die skeppingsorde of kosmiese wetsorde wat hier erg ter sake is. Die skepping is onteenseglik 'n eenheid en net so onteenseglik 'n verskeidenheid. Dit is die ou wysgerige probleem van die eenheid in die veelheid, en om in hierdie probleem die goeie weg te vind word van twee kosmologiese beginsels gebruik gemaak. Die eerste is die beginsel van soewereiniteit in eie kring wat dr. Abraham Kuyper reeds raakgesien het, en die tweede is die beginsel van universaliteit in eie kring. Die eerste waarborg die verskeidenheid in 
die skepping en die tweede die eenheid. Daar word ten minste veertien modale aspekte of ervaringswyses van die werklikheid onderskei, elkeen met 'n eie sinkern wat onherleibaar is tot die van enige ander modale aspek.

\section{Die modale aspekte}

Hierdie aspekte is die van (1) getal met die sinkern van diskrete kwantiteit of eïgheid, soos Van Riessen dit noem; (2) die ruimte met kontinue uitgebreidheid as sinkern; (3) die fisiese aspek met beweging of verandering as die kern; (4) die biotiese aspek met lewe as die kern; (5) die psigiese aspek met gevoel as die sinkern; (6) die analitiese aspek met logiese onderskeiding as die kern; (7) die historiese aspek met vrye vorming as die sinkern; (8) die taalaspek met sy kern van simboliese betekening; (9) die sosiale aspek met omgang en verkeer as die kern daarvan; (10) die ekonomiese aspek met besparing as die kern; (11) die estetiese aspek met harmonie as die kern; (12) die juridiese aspek met vergelding as die sinkern; (13) die morele aspek met liefde in tydelike betrekkings as die kern daarvan, en eindelik (14) die pistiese aspek met geloof as die kern daarvan. In elkeen van hierdie modale aspekte ofte wel wetskringe neem die skeppingsorde 'n eie modus aan. Die volgorde waarin die wetskringe hier genoem word staan in 'n vaste kosmiese tydsorde, en die tyd neem in elke kring 'n eie vorm aan.

Soos die beginsel van soewereiniteit in eie kring die eie geaardheid van die onderskeie modale aspekte van die ervaarbare werklikheid waarborg, so waarborg die kosmologiese beginsel van universaliteit in eie kring die samehang tussen die modale aspekte en daarmee die eenheid van die werklikheid. Volgens hierdie beginsel is daar in elke aspek, behalwe in die getalsaspek, terugverwysings (retrosipasies of analogië) na die voorafgaande of substraatkringe en vooruitwysings (antisipasies), behalwe in die geloofskring, na die daaropvolgende of superstraatkringe. So word die modaliteite in mekaar weerspieël. Van die twee grenskringe het die getalskring dus nie retrosipasies nie en die geloofskring nie antisipasies nie. Enkele voorbeelde van anti- en retrosipasies sal aanstons gegee word.

\section{Die subjek-objek relasie}

In elke modaliteit word daar tussen wet en subjek onder- 
skei. So is alle lewelose dinge onderworpe aan die wette van die eerste drie kringe, die van getal, ruimte en fisiese verandering. ' $\mathrm{n}$ Plant is ook aan hierdie wette onderworpe maar ook nog aan die biotiese wette; 'n dier reik een kring hoër, naamlik tot in die psigiese kring. Die mens is onderworpe aan die wette van al die kringe. Dit beklemtoon die hoë stand van die mens in die skepping. In daardie kringe waarin 'n ding geen subjekfunksies het nie kan dit objekfunksies hê. So bv. is 'n perd nie onderworpe aan die wette van die juridiese kring nie maar dit kan 'n objekfunksie in daardie kring hê as objek van 'n subjektiewe reg van 'n regsubjek. Objek is steeds objek vir 'n subjek in die kring waarin die subjek-objek relasie kan voorkom. So ook bv. het grond geen subjekfunksie in die biotiese kring nie maar wel 'n objeksfunksie as voedingsbodem vir 'n plant. Die bestaan van die plant is absoluut afhanklik van die bestaan van hierdie subjek-objek relasie.

\section{Natuur- en normatiewe sye}

In die modaliteite van getal, ruimte, verandering, biotiese en psigiese lewe, die sogenaamde natuursye van die skepping, is die kosmiese wetsorde in 'n vir die mens onaantasbare vorm gegee. In die modaliteite wat op hierdie modaliteite volg, die sogenaamde normatiewe sye, is die kosmiese wetsorde in die vorm van normatiewe beginsels gegee wat deur die mens, in gehoorsaamheid aan die skeppingsorde, nagespoor, aanvaar, gepositiveer (gevorm) en tot gelding in die samelewing gebring moet word. Dit is as gevolg van hierdie onderskeiding dat ons vandag 'n verdeling tussen natuur- en geesteswetenskappe het. Op grond van die beginsel van universaliteit in eie kring met sy retro- en antisipasies en die subjek-objek relasie, wat 'n struktuurbeginsel van die werklikheid is, kan hierdie tweedeling nie gehandhaaf word nie. Daarvoor is die eenheid van die skepping veels te onmiskenbaar. Oorbeklemtoning van die belangrikheid van die verskil tussen die natuur- en normatiewe sye lei m.i. noodwendig tot die denkmotief van natuur en vryheid wat nog steeds die transendentale grondlegging van die meeste gangbare vorms van die moderne wysbegeerte is. Die denkmotief van natuur en vryheid is 'n dialektiese motief, d.w.s. 'n denkmotief waarin die een pool steeds daarna streef om die ander te oorheers. So was daar 'n tyd toe die natuurwetenskaplike 
denke op die voetspore van Descartes en Hobbes, die sogenaamde geesteswetenskaplike denke oorheers het. Dit was die opkoms van die sogenaamde wetenskapsideaal. Die konsekwente deurvoering van hierdie soort denke het gedreig om die menslike persoonlikheid in sy normatiewe vryheid te vernietig, en Jean Jacques Rousseau was die eerste wat hierteen in opstand gekom het en die algehele vryheid van die mens op die voorgrond gestel het. So het die humanistiese persoonlikheidsideaal ontstaan, waarin die mens sy normatiewe vryheid oordryf en in die normatiewe sye van die skepping homself as soewereine wetgewer van wat reg en verkeerd is geproklameer het. Hierdie ideaal leef nog voort in die meeste wysgerige Westerse denkrigtings van vandag en is inderdaad ook die springbron van die moderne liberalisme. Kant het tevergeefs geprobeer om ' $n$ grensskeiding tussen natuur en vryheid te bewerkstellig, en na hom het die persoonlikheidsideaal gevolglik die oorhand begin kry.

Wat in hierdie verband onthou moet word is dat ons vandag nog, selfs in die reg, met die nawerking van die oordrewe natuurwetenskaplike denke te doen het. So sit ons bv. in die juridiese kousaliteitsleer nog met reste van die natuurnoodwendige kousaliteit, wat insig in die ware juridiese kousaliteit versper. Juridiese kousaliteit is in die eerste plek normatiewe kousaliteit en, hoewel dit nie sonder die retrosipasie op die natuurkousaliteit in die begrip gevat kan word nie, het dit tog 'n eie aard. So bv. het nalatigheid, wat geen verband hoegenaamd met natuurkousaliteit het nie, tog onteenseglik juridiese kousaliteit omdat dit 'n regsgrond vir 'n regsgevolg is. 'n $\mathrm{Na}$ latige handeling gryp steurend in die regsbelange in en dit vereis herstel van die geskonde regsbelange in die $\sin$ van vergelding. Juridiese kousaliteit berus dus in die laaste instansie op die afweging van die regsbelange.

\section{Begrip en idee}

In elke modaliteit of wetskring word daar tussen die begrip en idee daarvan onderskei. Die begrip van ' $n$ modaliteit is die sinkern van die modaliteit gevat in noue samehang met die retrosipasies van die betrokke modaliteit op die substraatkringe. So bv. is daar uit die juridiese kring retrosipasies of terugverwysings na die voorafgaande elf substraatkringe, en die sinkern 
van vergelding gevat in samehang met hierdie terugverwysings, gee die konstitutiewe elemente van die grondliggende of transendentale regsbegrip wat die juridiese denke eers moontlik makk. Dit is die regsbegrip in restriktiewe of onontslote funksie, en met hierdie begrip kan selfs die reg van primitiewe volke gevat word. So bv. kom die primitiewe reg nooit bo die beginsel van Erfolghaftung uit nie. Dit is die talio-beginsel van 'n oog vir 'n oog en 'n tand vir 'n tand.

Die idee van 'n wetskring is die kern gevat in samehang met die antisipasies of vooruitwysings na die superstraatkringe. Hierdie vooruitwysings hang ten nouste saam met die ontsluiting van die substraatkringe in die antisiperende of transendentale tydsrigting, en die regsidee lei en reguleer hierdie ontsluitingsproses. Die ontsluiting neem 'n aanvang in die historiese wetskring en staan onder leiding van die geloofskring. Hierdie ontsluitingsproses is wesenlik kultuurvorming op die grondslag van die historiese ontwikkeling wat in die kultuurhistoriese wetskring plaasvind. So het bv. die aanraking met naburige volke in die Romeinse tyd gelei tot die opkoms van die jus gentium wat die rigoristiese opvattings van die ou jus civile verruim en ten dele in die transendentale rigting ontsluit het. Mettertyd het die vooruitwysing van die juridiese kring na die morele kring met die sinkern van liefde daartoe gelei dat daar meer op die gesindheid van die oortreder as op die gevolge van sy handeling gelet is, en het die beginsel van straf na skuld die ou talio-beginsel vervang. In die burgerlike privaatreg het hierdie ontwikkeling gelei tot die beginsel van bona fides in privaatregtelike transaksies, en dit het die formularistiese opvattings van die kontrakreg van die ou jus civile vervang.

\section{Ontsluiting}

Hierdie ontsluiting in transendentale rigting het onder leiding van die regsidee plaasgevind, dog steeds op die grondslag van die kultuurhistoriese ontwikkeling wat die betrokke gemeenskap bereik het. Die regsidee is dus inderdaad 'n idee op mars wat die regsontwikkeling lei en self die groot dinamiese faktor in die regsvorming is. In teenstelling met die regsbegrip is die regsidee ' $n$ grensbegrip wat nie ten volle in die teoretiese begrip gevat kan word nie. Daarvoor is dit te veel afhanklik van die kultuurpeil wat reeds bereik is. Die mate waarin daar 
vooruitgesien kan word hang af van wat reeds bereik is. 'n Moderne voorbeeld is die afskaffing van slawerny. Tot in resente tye is die mens as sodanig nog as objek van 'n subjektiewe reg beskou, maar onder leiding van die regsidee het die Weste op ontslote kultuurpeil in opstand teen die idee van slawerny gekom. Die rede waarom slawerny nie juridies geregverdig kan word nie is dat die mens as sodanig, en afgesien van indiwiduele menslike handelinge, nie regsobjek vir 'n regsubjek kan wees nie. Die subjek-objek relasie, waarop die subjektiewe reg gebaseer is, vereis dat 'n regsubjek in die juridiese wetskring nie ook regsobjek in dieselfde wetskring kan wees nie. 'n Subjektiewe menslike handeling, soos dienslewering kan egter wel regsobjek in die juridiese kring vir 'n regsubjek wees. Daarop berus die regsfiguur van die huur van dienste. Hier is twee geoorloofde subjek-objek relasies in die spel wat in die dinamiek van die regslewe teen mekaar uitgeruil word, naamlik die tussen die werkgewer en die dienslewering wat hy ontvang en die tussen die werknemer en die vergoeding wat hy vir sy dienste kry. So ook is 'n subjektiewe onregmatige handeling regsobjek in die juridiese kring. Dit is 'n verbode subjek-objek relasie waarin die aangeklaagde teenoor sy eie wandaad te staan kom. Dit is die subjek-objek relasie waarmee 'n mens in elke strafgeding te doen het, en omdat dit 'n verbode subjek-objek relasie is moet dit deur vergelding in die sin van straf, wat die geskonde regsbelange herstel, ongedaan gemaak word.

Soos uit hierdie voorbeelde blyk, word die wetsy en subjeksy van 'n wetskring steeds in noue korrelasie met mekaar gevat. In die juridiese kring bv. word die norme aan die wetsy steeds op die subjektiewe regswerklikheid aan die subjeksy betrek.

\section{Transendentale regsbegrip}

Ten einde nader aan die kernprobleme van die regsvorming te kom is dit dienstig om hier 'n kort samevatting van die transendentale regsbegrip te gee, maar dan met die waarskuwing daarby dat hierdie begrip so ryk van inhoud is dat dit kwalik in 'n formule saamgevat kan word. Dit is hier egter nodig ten einde enkele retrosipasies wat vir die regsvorming onontbeerlik is aan die lig te bring. Dit lui soos volg: 
1. Die reg volgens die algemene sin van die wetsy van die juridiese wetskring is die eenheid in die veelheid, volgens die korrelasie van gemeenskaps- en maatskapsfunksies, van die aan die wil van kompetente organe toe te rekene en uit goddelike beginsels gepositiveerde norme met bepaalde betekenis, geldingsgebied en geldingstyd, wat na gronde en gevolge, in die samehang van gebiedende en veroorlowende funksies, deur harmoniese afweging die ewemaat reguleer in die veelheid van menslike belange in die sinkern van vergelding.

2. Die reg volgens die algemene sin van die subjeksy van die juridiese wetskring is die eenheid in die veelheid van tot die subjektiewe wilsfunksies toe te rekene subjek-objek relasies wat, plaaslik en tydelik sebonde, in die korrelasie van gemeenskaps- en maatskapsbevoegdhede en -pligte van hul subjekte, volgens hul positiewe betekenis in ooreenstemming of in stryd met die norm, kousaal is vir die harmoniese ewewig van die regsbelange in die sinkern van die vergelding.

\section{Retrosipasies}

Harmoniese afweging aan die wetsy en harmoniese ewewig aan die subjeksy is ' $n$ retrosipasie op die estetiese kring. Die regsnorme harmonieer die regsbelange deur hul teen mekaar af te weeg en onregmatige gedragings eis dwingend 'n narmoniërende reaksie ingevolge die regsnorme waardeur die onreg opgehef en versoen word. Die ewemaat en ewewig is terugverwysings na die ekonomiese kring. Aan die wetsy moet daar vergeldingsharmonie kom deur die vergeldingsewemaat tussen regsgrond en regsgevolg te vind. Die juridiese ekonomie verbied die ekses van regsmag en die eksessiewe vervolging van regsbelange ten koste van gelyke of meerderwaardige belange. Aan die subjeksy moet die ewewig tussen die betrokke regsbelange in die sin van vergelding herstel word. Die korrelasie van gemeenskaps- en maatskapsfunksies aan die wetsy en die gemeenskaps- en maatskapsbevoegdhede en -pligte is terugverwysings na die kring van sosiale verkeer. In die maatskapsverhouding staan die regsubjekte gekoôrdineerd naas mekaar soos in 'n kontrak, maar in die gemeenskapsverhouding is hulle onderworpe aan die gesag van die gemeenskap waaraan hulle behoort, bv. lede van dieselfde kerk- en staatsverband. Die omgangsin openbaar homself noodwendig in 'n korrelasie van gemeen- 
skaps- en maatskapsfunksies. Hierdie korrelasie is 'n retrosipasie aan die wetsy en dit vereis noodwendig ' $n$ korrelasie van gemeenskaps- en maatskapsnorme. Aan die subjeksy vereis die retrosipasie 'n korrelasie van gemeenskaps- en maatskapsregte en -verpligtings. Sosiale omgang en die regsverkeersaspek daarvan is alleen bestaanbaar op die substraat van die taalkring met die sinkern van simboliese betekening. Die retrosipasie op die taalkring aan die wetsy is die juridieke betekenis van die regsnorme en aan die wetsy die regsbetekenis van subjektiewe en objektiewe regsfeite. Ook hier vereis vasstelling van die regsbetekenis afweging in die weegskaal van die vergelding. Die taal is alreeds 'n kultuurproduk, en dit verwys terug na die kultuurhistoriese kring met die sinkern van vorming volgens vrye ontwerp. Vorming impliseer mag, en in hierdie kring openbaar die kernmoment hom aan die wetsy as vormende mag oor persone en aan die subjeksy as vormende mag oor dinge, d.w.s. van kultuurobjekte, materieel sowel as geestelik. Aan die wetsy is daar dus mag oor regsubjekte en aan die subjeksy mag oor regsobjekte. Aan die wetsy word die mag uitgeoefen in die positivering van die regsnorme en aan die subjeksy deur die vorming van regsobjekte en die verrigting van handelinge wat in die subjek-objek relasie kan optree. In die retrosiperende rigting is die logiese kring die laaste normatiewe wetskring, en die sinkern is logiese onderskeiding. Handelinge wat regsgevolge het is normatiewe handelinge en sonder logiese onderskeiding kan daar van normatiewe handelinge geen sprake wees nie. Vir die positivering van normatiewe regsbeginsels is logiese onderskeiding ook 'n vereiste, en die norms wat gepositiveer word moet noodwendig aan die normatiewe vormingswil van die regsvormer toegereken word. Dit is die logiese retrosipasie aan die wetsy van die juridiese kring. Korrelaat aan die normmoment aan die wetsy is die pligsmoment aan die subjeksy. Subjektiewe gedragings in ooreenstemming of in stryd met die regsnorme word aan die wilsfunksie van die regsubjek toegereken. Handelinge in ooreenstemming of in stryd met die regsnorme berus op die sinsubstraat van die logiese beginsel van teenspraak (principium (excludendae) contradictionis) en toerekening berus op die logiese beginsels van toereikende grond (principium rationis sufficientis). Toerekening van die gepositiveerde regsnorm aan die wil van 'n kompetente regsvormer en toerekening van 'n subjektiewe regsfeit aan die wil 
van 'n regsubjek wat aan die norm onderworpe is, wys verder terug na die psigiese wetskring. Die sinkern van hierdie kring is gevoel. Die Psigiese kring is die hoogste kring in die natuursye van die skepping. Dit bring ons die wilsmoment wat nie sonder die substraat van die gevoel kan bestaan nie. By die mens kom die wil egter onder die klem van die normatiewe aspekte van die superstraatkringe. In teenstelling met die dier is die menslike wil 'n normatiewe wil. Die mens moet sy wil na die norm rig. Die uitgang van die wil is die hart van die mens, en dit is in die hart waarin die mens se aktstruktuur gesetel is, d.w.s. die sentrum van sy selfheid waarin hy kennend, verbeeldend en willend met die werklikheid besig is. Die wilsakte wat uit hierdie dieptes opkom konkretiseer homself in 'n wilsbesluit wat daarna deur 'n handeling veruitwendig word. Hier moet egter tussen die psigiese en juridiese aspekte van die wilsakte onderskei word. Selfs die psigiese aspek van die wilshandeling moet uit die normatiewe aspekte benader word om hom vir sy handeling verantwoordelik te stel. Hier lê ook die onderskeid tussen die psigologiese wilsbegrip en die juridiese wilsbegrip. Die psigologiese wilsbegrip kan omskryf word as die gevoelige impulsiewe aandrif om in vry normaitewe aktiwiteit 'n bepaalde voorgestelde doel te bereik. In die juridiese wilsbegrip het ons te doen met die vraag of die wilsakte volgens die regsnorme genormeer is. Die regsubjek se wilsuiting is sy juridiese wilsverklaring en daaruit moet sy opset afgelei word. Die wilsverklaring kan of 'n eksplisiete verklaring wees soos die van 'n wetgewer of 'n subjektiewe handeling, soos 'n onregmatige daad, waaruit die wil afgelees moet word. $\mathrm{Na}$ die wetsy bestaan die retrosipasie op die psigiese kring in die ordeningswil van die regsvormer en na die subjeksy in die ordeningswil van die regsubjek wat aan die regsnorme onderworpe is. Die regslewe met sy labiele ewewig van regsbelange wat deur die norme gereguleer word wys ook terug na die kring van die organiese lewe. Die orgaangedagte moet hier egter juridies in die sin van 'n amp gevat word. Aan die wetsy is die retrosipasie (of analogie) die regsorgaan wat die reg vorm en aan die subjeksy openbaar die analogie hom in die ontstaan en tot niet gaan van feitlike regsbetrekkings, van subjektiewe regte en pligte en van die regsubjektiwiteit as geheel. Elkeen van hierdie dinge het ' $n$ bepaalde lewensduur. Lewe veronderstel beweging, en dit bring ons by die analogie in die fisiese kring met sy beweging 
of energie-werking. Aan die wetsy verbind die norme sekere regsgevolge aan sekere gronde en aan die subjeksy lewer die subjektiewe en objektiewe feite die gronde vir die intree van die gevolge wat die norms aan die feite heg. Kousaliteit moet hier juridies in normatiewe sin gevat word en wel as vergeldingskousaliteit wat die ewewig van regsbelange herstel. Beweging weer veronderstel ruimte waarin dit plaasvind. Aan die wetsy is die ruimte-analogie die geldingsgebied van die regsnorme en aan die subjeksy is dit die plek waar 'n regsfeit tot stand gekom het. Hier kan ruimte nie in die originêre sin van kontinue uitgebreidheid gevat word nie maar moet in normatief juridiese sin gevat word. Dink maar aan die personele gelding van sekere regsnorme. Die retrosipasie uit die juridiese kring wat die diepste reik is die na die getalskring. Hierdie retrosipasie is omvattend en slegs enkele aspekte daarvan kan genoem word. Aan die wetsy is die regsnorm 'n eenheid wat 'n veelheid van indiwiduele gevalle beheers. So is die regsorde self ' $n$ eenheid in die veelheid van die regsnorme wat daarin begrepe is. Aan die subjeksy is die regsubjek ' $n$ eenheid in die veelheid van gemeenskaps- en maatskapsverhoudings en in die veelheid van regsbetrekkings waarin dit staan. Ook 'n regsfeit is ' $n$ eenheid in 'n veelheid van regsverhoudings en regsgevolge.

\section{Kategoriale begrippe}

Die retrosipasies of analogië uit die juridiese wetskring wat hierbo kortliks aangedui is, is die clementêre grondbegrippe van die reg, maar daarmee is volledige insig in die regsbegrip nog nie moontlik nie. Daar is ook nog samegestelde modale grondbegrippe. Dit is nie begrippe wat, soos die elementêre grondbegrippe, op 'n bepaalde analogie-sfeer van die modale struktuur van die juridiese wetskring betrokke is nie maar wat alle elementêre begrippe in hulle saamvat. Hierdie komplekse begrippe is modale totaalbegrippe waarin die modaal onderskeie analogieë volgens verskillende gesigspunte, wat nie self van modale aard is nie, maar aan alle modale aspekte ten grondslag lê, in 'n totaalsintese saamgetrek word. Dit is gesigspunte wat net soos die van die modale struktuur van 'n wetskring self, van kategoriale karakter is. Die kategoriale gesigspunte wat hier van belang is, is die van die wet- en subjeksye van 
'n wetskring, die subjek-objek relasie en die relasie van ontstaan en tot niet gaan. Dit is transendentale relasies wat in die inter-modale samehang van die modale aspekte in die kosmiese tydsorde gegrond is. Die kategoriale gesigspunte betrek die modale aspekte op die inter-modale samehang van die aspekte en op die indiwidualiteitstrukture van die ervaarbare werklikheid.

\section{Indiwidualiteitstrukture}

In hierdie verband is dit nodig om daarop te wys dat die werklikheid nie in sy sinfunksionele of modale aspekte opgaan nie. In die nailewe ervaring ervaar ons die werklikheid in sy dingstruktuur deur middel van aie subjek-objek relasie as 'n integrale eenheid. Hier is die modale aspekte, wat met die funksie-begrip gevat word, nog 'n integrale eenheid en die verskillende indiwidualiteitstrukture word slegs met die dingbegrip gevat, sonder om die modale aspekte te onderskei. Dit is nie moontlik om hier verder op die leer van indiwidualiteitstrukture in te gaan nie, maar dis tog nodig om enkele voorbeelde te gee. Die staat as samelewingsvorm is so 'n struktuur en berus op historiese magsvorming. Dit is sy fundering, maar sy bestemming lê in die juridiese kring en self is dit 'n regsgemeenskap van owerheid en onderdane. Die kerk weer is ook histories gefundeer maar het sy bestemming in die geloofskring. Die huwelik is bioties gefundeer en vind sy bestemming in die morele kring met liefde as die kern daarvan. Ook konkrete dinge het hierdie soort struktuur. 'n Kerkgebou bv. is kultuurhistories gefundeer maar het sy bestemming in die geloofskring as vergaderplek vir die geloofsgenote. 'n Sakegebou se bestemming weer lê in die ekonomiese kring. So ook het menslike handelinge verskillende bestemmings. 'n Gebed is pisties gekwalifiseer maar die sluiting van 'n kontrak het 'n juridiese bestemming. 'n Dingstruktuur het subjek- en objekfunksies in al die modale aspekte van die werklikheid. Omdat die mens geen sodanige objeksfunksies het nie kan dit nie as 'n indiwidualiteitstruktuur beskou word nie. Die mens het 'n transkosmiese en ewigheidsbestemming.

Dit is nie moontlik om hier verder op die drie genoemde kategoriale relasies in te gaan nie behalwe om te noem dat die komplekse begrippe regsnorm en regsfeit uit die relasie van 
wet- en subjeksye ontstaan; dat die komplekse regsbegrippe van regsubjek en regsobjek uit die subjek-objek relasie ontstaan en dat uit die relasie van ontstaan en tot niet gaan die komplekse begrip regsbron ontspring. Dit is noodwendig so omdat die regsvorming met die kultuurontwikkeling saamhang.

Daarmee is die transendentale regsbegrip vir die huidige doeleindes redelik voldoende toegelig, sodat daar nou aandag aan die proses van regsvorming gegee kan word.

\section{Regsbron}

Soos reeds opgemerk is die begrip regsbron 'n samegestelde begrip. Dit bring mee dat die reg nie net as sinfunksionele begrip gevat kan word soos die modaal-juridiese gesigspunt vereis nie. In die regsvorming stuit ons op die volle dingwerklikheid van die regslewe, en hier moet die dingbegrip voortdurend in onderlinge samehang met die funksiebegrip gehanteer word. In die regsvorming het ons naamlik te doen met die wetsy van die juridiese kring en die vormingselement wat 'n subjektiewe menslike handeling is. Dit bring ons by die bronne van die positiewe reg. Die kern van die regsbronne-probleem sit in die uiteenstelling van die innerlike kompetensiesfere vir die regsvorming wat in die sinstruktuur van die regslewe self geleë is en in die vraag hoe, ten spyte van die veelheid van die onderling onherleibare kompetensiesfere, hulle onderlinge samehang nogtans binne die eenheid van die regsorde self te verstaan is. Dit is hier waar die grondliggende regsbegrip onontbeerlik blyk te wees, want die regsbronne-probleem is inderdaad die sleutelprobleem vir die hele regswetenskap as vakwetenskap.

Die volgende rigtingwysers moet hier voorop gestel word: (1) Die soewereiniteit van die reg as 'n eie modale aspek van die werklikheid moet gehandhaaf word en tog moet die sinsamehang van die reg met die tydelike werklikheid gevat word. As ' $n$ vereiste is hieraan reeds in die regsbegrip voldoen. (2) Die formele element in die regsbron is noodsaaklik, want na die wetsy van die juridiese kring vereis die reg subjektiewe vorming van goddelike regsbeginsels deur bevoegde menslike organe. Sulke vorms is wette, ordonnansies, reglemente, kontrakte, vonnisse, ens. Wat in hierdie vorms as reg gepositiveer word is nie noodwendig positiewe reg nie, omdat 'n juridiese 
ontstaansvorm as sodanig nooit $\mathrm{n}$ juridiese geldingsbron kan wees soos die positivisme leer nie. Die positivisme oordryf en verabsoluteer die menslike vormingselement (die kultuurhistoriese analogie) en daarmee word die reg aan die willekeur van die wetgewer uitgelewer en hou dit geen verband met die modale sin van die reg volgens die kosmiese wetsorde nie. Ek kom later op hierdie punt terug. (3) Die modale sinfunksionele begrip kan nie van die dingstrukture van die werklikheid volle rekenskap gee nie, en daarom is die dingbegrip nodig om die verbande van die menslike samelewing as normatiewe dingstrukture te vat. Soos reeds vermeld is die staat en kerk voorbeelde van hierdie indiwidualiteitstrukture. Elkeen van hierdie dingstrukture het 'n eie interne regsfeer wat nie van die regsfeer van enige ander verband afgelei kan word nie. Hierdie dingstrukture is gemeenskapstrukture. Dan is daar nog die maatskapsverhoudings, soos bv. kontraktuele verhoudings, wat ook 'n eie interne regsfeer het. Hierdie verskillende regsfere is ' $n$ kompetensie-ordening wat in die skeppingsorde gewortel is en hierdie ordening is die kardinale probleem van die regsbronne-teorie. Aangesien die regsvorming op die regsverkeer toegespits is kom die terugverwysing na die sosiale kring hier in aanmerking, en dit lei tot die sinsverband en sinsverskil tussen die regsnorme en die sosiale verkeersnorme. (4) Die regsbronne-teorie moet ook die onderlinge verhoudinge en samehang van die regsbronne ophelder. Hierdie rigsnoere moet ons gedagtes oor regsvorming verder lei.

\section{Positiwiteit en gelding}

Blote positivering skep nog geen geldende reg nie, want die gelding van regsnorme berus op die konstante positivering deur die organe wat in die betrokke lewensverhoudings daartoe bevoeg is, van die materiële goddelike regsbeginsels, soos dit op die betrokke kultuurhistoriese peil verstaan word. Positiwiteit en gelding van die regsnorme is daarom onafskeidelik verbonde, maar die gelding sien meer op die beginselgrondslag van die norme en die positiwiteit op die menslike vorming van die norme deur kompetente organe. In die lig van hierdie opmerkings kan 'n regsbron omskryf word as elke juridiese vorm (of wilsverklaring) waarin die tot regsvorming kompetente organe van die verskillende gemeenskaps- en maatskaps- 
kringe binne hul materieel-juridiese kompetensiesfere, in wederkerige bindings van hierdie kompetensiesfere, op kultuurhistoriese grondslag, materiële regsbeginsels tot geldende reg positiveer. Die kultuurhistoriese analogie self vereis 'n juridiese ontstaansvorm as regsbron in formele sin. Die kultuurhistoriese analogie self moet gevat word in samehang met die biotiese, psigiese, logiese en simboliese analogieë, en die ontstaansvorm self moet gesien word as die direkte of indirekte wilsverklaring wat toe te reken is aan 'n met regsmag beklede orgaan en gerig is op juridiese vormgewing, op kultuurhistoriese basis, aan regsbeginsels wat daardeur (op grond van die bewegingsanalogie) in die proses van positivering opgeneem word en die positiewe regsbetekenis waarvan deur juridiese interpretasie van die formulering vasgestel moet word. Verder vereis die sosiale omgangsanalogie dat die wilsverklaring op die regsverkeer tussen die regsgenote betrek moet wees. Soos reeds opgemerk vertoon hierdie regsverkeer 'n korrelasie van gemeenskaps- en maatskapsverhoudings wat tred hou met die sosiale aard van die regsnorms. Dit hang ook saam met die kompetensiesfere van die regsvormende organe en met die regsbeginsels waaraan die organe vorm gee. Sonder juridiese vormgewing verloor die regsbeginsels ook hul onvermydelike verband met die feitlike sy van die juridiese wetskring. Uitdruklike vormgewing word ook deur die beginsel van regsekerheid vereis.

\section{Ontstaansvorms}

Die juridiese ontstaansvorm kan op 'n direkte of indirekte wyse tot stand kom namate die wilsverklaring regstreeks of onregstreeks geskied. In die eerste geval word die wilsverklaring uitdruklik uitgespreek, soos in 'n wet van die Parlement, en in die tweede geval bestaan die vasstelling van die norm uit 'n reeks konstante gedraginge waarin dieselfde regsreël tot uitdrukking kom. Die wyse waarop die reg ontstaan moet egter nie met die formeel-juridiese ontstaansvorme (die wilsverklaring) verwar word nie. Dit is slegs kenbronne van die wilsverklaring wat deur juridieke interpretasie vasgestel moet word. So bv. kan gewoonte nie self 'n juridiese ontstaansvorm van reg wees nie maar alleen ' $n$ indirekte kenbron van die wilsverklaring van 'n bevoegde regsvormer. Sodra die gewoonte egter as ' $\mathrm{n}$ regterlike vonnis erken word is die vonnis die formeel- 
juridiese ontstaansvorm van die reg wat inter partes daarin gepositiveer is. 'n Ander voorbeeld van 'n indirekte ontstaanswyse van die reg is die sogenaamde ,conventions of the constitution" van die Britse Parlementêre stelsel. Hier gedra die regsvormende organe hulle op 'n wyse wat 'n kenbron van indirekte regsvorming is. Hier kan ook die volkeregtelike gewoonte genoem word wat geen ander oorspronklike bevoegde orgaan as die state self het nie en alleen deur regsvormende onderlinge wilsooreenstemming van die state self gepositiveer kan word.

Net soos die juridiese ontstaansvorme behoort ook die formeel-juridiese gelding van die regsnorme tot die formele deel van die regsbronne-teorie. Formeel-juridiese gelding kom toe aan die uitdruklike juridiese ontstaansvorm in regsvorming wat op delegasie van 'n hoëre wetgewende orgaan berus, bv. regulasies gemaak ingevolge ' $n$ Wet. Dit is gevolglik die gelding wat 'n regsreël besit bloot uit hoofde van die feit dat dit in 'n gedelegeerde ontstaansvorm gepositiveer is. Formeel-juridiese gelding behoort nie tot die begrip regsbron nie.

\section{Materieel-juridiese kompetensie}

Met die materieel-juridiese kompetensiemoment kom ons by die kern van die regsbronne-probleem en die proses van regsvorming. Hierdie moment berus op die soewereiniteit in eie kring van die samelewingsverbande en die maatskapsverhoudings en hiervan hang ook die materieel-juridiese gelding van die regsnorme af. Dit is die essensiële gelding van die reg, en 'n regsnorm geld slegs as dit binne die materiële kompetensiesfeer van 'n kompetente orgaan vormgewing aan bo-willekeurige beginsels is waaraan die regsvormer self onderworpe is. Om materiële gelding te kan hê moet 'n regsnorm voortdurend in indiwiduele gevalle deur die daartoe kompetente organe gekonkretiseer en toegepas word. Hierdie indiwidualisering van die regsnorm behoort tot die wese van 'n regsnorm. In die regspraak word die voorpresessuele norm nader op die konkrete geval toegepas en daardeur ook nader gepositiveer. In hierdie $\sin$ is die regter ' $n$ kompetente regsvormende orgaan. In die proses van nadere positivering is die juridieke interpretasie van die voorprosessuele regsnorm ook 'n vorm van regsvorming. 
Die omvang van die materieel-juridiese kompetensiemoment is van die kultuurhistoriese ontwikkeling afhanklik, maar die interne struktuur van die gemeenskaps- en maatskapskringe kan nie van die kultuurhistoriese ontwikkeling afhanklik wees nie omdat die struktuur daarvan in die kosmiese wetsorde veranker sit. Dit is struktuurwette van die volle tydelike werklikheid. Uit hierdie struktuurwette vloei ook voort die tipiese regsbeginsels, en hierdie beginsels is van 'n konstante transendentale karakter omdat hulle ons ervaring van die wisselende en in die tyd verganklike positiewe samelewingsverhoudings eers moontlik maak. Hier kom ons weer by die idee van die korrelasie van die gemeenskaps- en maatskapsverhoudings, en in verband met die gemeenskapskringe dien opgemerk te word dat hulle ook, wat hul eksterne verhoudings betref, in maatskapsverhoudings staan. In beide die gemeenskaps- en maatskapsverhoudings het ons inderdaad met inter-menslike verhoudings te doen en ook met die subjek-objek relasies wat daarin fungeer en wat van deurslaggewende betekenis vir die suksesvolle bestaan van daardie verhoudings is. Die kwessie van inter-menslike verhoudings en die subjek-objek relasies wat daarmee saamhang is 'n magtige onderwerp waarop nie hier verder ingegaan kan word nie maar wat ek hoop om op 'n ander geleentheid meer breedvoerig te bespreek.

\section{Burgerlike privaatreg}

Die burgerlike privaatreg is 'n jus commune vir die vrye maatskaplike verkeer van die regsgenote wat hulle op die grondgebied van die staat bevind. Hierdie jus commune is nie, soos die interne verbandsreg bv. die van die kerk, buite-juridies gekwalifiseer nie, en vereis vorming deur die staat as die enigste regsgemeenskap van owerheid en onderdane binne die gebied van die staat. Die deur die staat gepositiveerde burgerlike privaatreg is ' $n$ integreringsreg waarmee die interne verbandsreg van die samelewingsverbande iǹ hulle eksterne matskapsverhoudings enkapties vervleg is. So bv. is die interne kerkreg of die maatskappyreg in die eksterne verhoudings waarin daardie soorte verbande optree, aan die burgerlike privaatreg gebonde ten einde 'n ordelike regsverkeer binne die staatsverband te verseker. Hierdie integreringsreg van die staat mag die interne regsfere van die verbands- en maatskapskringe nie aan- 
tas nie, omdat daardeur die interne materiële kompetensiesfere van laasgenoemde ontken word. Hierdie stelling weer is 'n uitvloeisel van die beginsel van soewereiniteit in eie kring van die genoemde gemeenskaps- en maatskapstrukture, en dit is uiteindelik die waarborg dat die staat as regstaat en nie as magstaat sal funksioneer nie.

Die vervlegting van die verbandsreg en maatskapsreg met die burgerlike privaatreg is in die ontstaansvorme van die reg te vind. So bv. is die oprigting van ' $n$ maatskappy of die stigting van 'n vereniging gebonde aan die voorskrifte wat die burgerlike privaatreg, met die oog op die regsverkeer, daarvoor neerlê. Die ontstaansvorm bepaal egter niks oor die interne verbandsof maatskapsreg nie en daarom kan die vervlegting alleen in die ontstaansvorms gevind word.

\section{Suid-Afrikaanse regstoneel}

As ons nou in die lig van die voorgaande opmerkings 'n vlugtige blik op die Suid-Afrikaanse regstoneel werp, dan kan met dankbaarheid gekonstateer word dat ons hoogste hof hom dit steeds ten doel stel om ons gemenereg, wat 'n kultuurbesit uit vervloë tye met ' $n$ ander kultuurpeil is, by ons veranderde omstandighede en 'n ander, in baie opsigte, hoër kultuurpeil aan te pas. Dit is 'n erkenning van die feit dat die materiële regsbeginsels aan die kultuurhistoriese ontwikkeling gebonde is aan en met daardie ontwikkeling tred moet hou. Aan die debietkant moet egter gekonstateer word dat ons regswetenskap nog steeds te bevange is in die positivistiese regsleer wat van Engelse oorsprong is en hier te lande deur die gebruik van Engelse teksboeke in die hand gewerk is en nog word. Ek kan volstaan met een voorbeeld. Ons gemenereg het die reël geken dat 'n regsbepalings sy materieel-juridiese gelding deur gebrek aan konstante positivering in die regspraktyk kan verloor en in onbruik kan geraak - vide Green vs Fitzgerald \& Others, 1914 A.D. 88 op bl. 110. Dit is 'n heeltemal in ooreenstemming met wat hierbo in verband met die materieel-juridiese gelding van die regsnorme verduidelik is. Vandat die invloed van die Engelse positivistiese regsbeskouing in Suid-Afrika gangbaar geword het is bepaal dat ' $n$ statutêre bepaling nooit deur onbruik kan verval nie. Dit is 'n direkte uitvloeisel van die positivistiese regsbegrip dat alle reg wetgewerswil is en dat die regsnorme 
hul gelding ontleen bloot uit die feit dat die norm in ' $n$ juridiese ontstaansvorm gepositiveer is. Hier is verwarring tussen die formeel-juridiese en materieel-juridiese gelding van die regsnorme. So kan daar nog meer voorbeelde van positivistiese invloed genoem word, maar die tyd is reeds verstreke. Ons taak is steeds om daardie invloed beter te leer ken en uit ons regswetenskap te elimineer.

\section{Besluit}

Wat ek hier in die midde probeer lê het is hoofsaaklik gebaseer op die grondbeginsels van die Wysbegeerte van die Wetsidee en die regswetenskap wat Herman Dooyeweerd en sy medestanders daaruit ontwikkel het. Ek betuig graag my dank aan hulle vir die verryking wat my eie denke aan hulle werk te danke het. Hulle werk gee voor Christelik-wetenskaplik te wees, soos dit m.i. ook inderdaad is.

Almal sal nie die beskouing onderskryf dat die wysbegeerte en vakwetenskappe op Christelike grondslag die oplossing van die diepste teoretiese probleme kan gee nie. Ons wat dit wel glo kan egter rustig op hierdie grondslag voortbou in die wete dat die uiteindelike welslae van die Christelike wetenskap nie van die stryd van die menings afhanklik is nie maar alleen van die mate waarin dit slaag om die werklikheid te verklaar waar wysgerige en vakwetenskaplike beskouings, wat uit 'n nie-Christelike wortel opkom, nie tot dieselfde mate daarin kan slaag om die probleme, wat binne die menslike ervaringshorison teëgekom word op te los nie. Dit is die Waarheid self wat uiteindelik sal beslis.

Kimberley.

G. F. de V. Hugo 